\title{
Student Teams Achievement Division with a Learning Video to Increase Students`Achievements and Learning Motivation in Social Science Learning
}

\author{
Ais Murjianti' ${ }^{1}$, Hermanu Joebagio ${ }^{2}$, Nunuk Suryani ${ }^{3}$ \\ ${ }_{1}^{1}$ Universitas Sebelas Maret, Surakarta, Indonesia \\ 2 Universitas Sebelas Maret, Surakarta, Indonesia \\ 3 Universitas Sebelas Maret, Surakarta, Indonesia
}

1aismurjianti@yahoo.co.id, 2hermanu.joebagio@gmail.com,33nunuk_suryani_uns@yahoo.com

\begin{tabular}{ccc}
\hline Received & Accepted & Published \\
$05 / 09 / 2018$ & $10 / 10 / 2018$ & $31 / 12 / 2018$ \\
\hline
\end{tabular}

Abstract This research aims to measure the effectiveness of the implementation of learning model STAD using video to improve the students' motivation and students 'achievement. The type of this research is classroom action research, that is conducted at Sidoharjo Junior High School 2 Sragen, Indonesia. The implementation of cooperative learning with STAD model using video could improve the students' learning achievement. The average score was 76,13 , and the percentage of minimal classical completeness reach 87, $09 \%$. However, perceived on the classical completeness criteria, all of the students have completed the criteria, and reach $85 \%$ of the learning target. The implementation of STAD using natural resources video could improve the student's motivation. The result of the research shows the average score of $83,97 \%$, and the percentage of minimum criteria shows $80 \%$.

Keywords: Students Team Achievement Division (STAD), video, students` achievement, students` learning motivation

\begin{abstract}
Abstrak Penelitian ini bertujuan untuk mengukur efektivitas penerapan model pembelajaran STAD menggunakan video untuk meningkatkan motivasi belajar dan prestasi siswa. Jenis penelitian ini adalah penelitian tindakan kelas, yang dilakukan di SMP Sidoharjo 2 Sragen, Indonesia. Implementasi pembelajaran kooperatif dengan model STAD menggunakan video dapat meningkatkan prestasi belajar siswa. Skor rata-rata adalah 76, 13 dan persentase ketuntasan klasikal minimal mencapai 87,09\%. Namun, dilihat dari kriteria ketuntasan klasikal, semua siswa telah memenuhi kriteria, dan mencapai 85\% dari target pembelajaran. Implementasi STAD menggunakan video sumber daya alam dapat meningkatkan motivasi siswa. Hasil penelitian menunjukkan skor rata-rata 83, 97\%, dan persentase kriteria minimal menunjukkan $80 \%$.
\end{abstract}

Kata kunci : Students Team Achievement Division (STAD), video, prestasi siswa, motivasi belajar siswa 


\section{INTRODUCTION}

The current pattern of students ' perception towards the learning subject has shown that the students feel it disinterests to learn social science in comparison with others subject such as math, Indonesian language, English language, science education. Consequently, the students' achievement and learning motivation in learning social science are low. The authors perceive that, structurally, six factors cause low learning achievement and learning motivation in social science learning. First, the Indonesian National Curriculum of 2013 (K13) obligates teachers to use an integrated approach in social science learning. Second, the K13 drives teachers to the used scientific approach. Third, teachers unable to utilise learning resources and monotony use books as their teaching resources. Fourth, the teacher is unable to fulfil all the requirements of K13. Fifth, the less availability of reference books. Sixth, the student's assessment focused on the cognitive aspect.

Besides those factors, the authors argue that there is a primary factor that causes low learning achievement: social science is not a part of the national examination. Thus, the student underestimates it. The low learning achievement and learning motivation cause a negative impact. Motivation is a particular element that could increase the quality and intensity of learning quality. Besides that, the students have the low creativity to seek relevant resources, which comes from the creativity, activity, and autonomy of the students.

Based on those problems, the authors believe that the teachers should elevate the learning process of social science by transforming the learning approach from conventional to be more actively approach. It means teachers should find an appropriate learning model and strategy that emphasise on the cooperation among students. In this strategy, the learning process is focused on the students' activity, or popularly known as student-centred learning. In this learning approach, teachers take a role as a facilitator that provoke a various learning model and strategy, such as question and ask, discussion, socio-drama, teamwork. Those learning approaches are flexible, democratic, and could develop the cognitive, affective, and psychomotor aspect of the students. Others learning approach, which less involving the students` in a learning activity, would cause the decrease of students` learning motivation, and along with this, it also causes the decrease of students` learning achievement.

Therefore, teachers should pursue to endorse students`activity in learning social sciences to increase students' learning motivation and learning achievement. The authors agree that those problems solved with the implementation of Student Team Achievement Division (STAD) learning strategy. The learning syntax of STAD sees in table 1. 
Table 1. The Learning Syntax of STAD

\begin{tabular}{|c|c|}
\hline Learning Stages & Teachers Activities \\
\hline $\begin{array}{l}\text { Stage 1 } \\
\text { Delivering the purposes of learning and } \\
\text { motivating the students }\end{array}$ & $\begin{array}{l}\text { Delivering the purposes and objectives of } \\
\text { learning that should be achieved by } \\
\text { students in the learning process. } \\
\text { Motivating the students to be ready for } \\
\text { the learning process }\end{array}$ \\
\hline $\begin{array}{l}\text { Stage } 2 \\
\text { Delivering the learning material }\end{array}$ & $\begin{array}{l}\text { Delivering the learning material to } \\
\text { students by demonstrating or collectively } \\
\text { reading the references }\end{array}$ \\
\hline $\begin{array}{l}\text { Stage } 3 \\
\text { Organising the students into groups of } \\
\text { learning }\end{array}$ & $\begin{array}{l}\text { Explaining to the students how to make a } \\
\text { group and then help the groups to do } \\
\text { transition efficiently }\end{array}$ \\
\hline $\begin{array}{l}\text { Stage } 4 \\
\text { Guiding the groups to works and learn } \\
\text { collectively }\end{array}$ & $\begin{array}{l}\text { Guiding the learning groups to work on } \\
\text { the tasks and exercises }\end{array}$ \\
\hline $\begin{array}{l}\text { Stage } 5 \\
\text { Evaluating }\end{array}$ & $\begin{array}{l}\text { Evaluating the result of the learning } \\
\text { process. Meanwhile, the learning groups } \\
\text { present their result of learning in front of } \\
\text { the classroom. }\end{array}$ \\
\hline $\begin{array}{l}\text { Stage } 6 \\
\text { Giving achievement }\end{array}$ & $\begin{array}{l}\text { Find a way to achieving the result of the } \\
\text { learning process }\end{array}$ \\
\hline
\end{tabular}

Source: Rusman (2012: 211)

Theoretically, the STAD learning model would involve the students more deeply in the learning process as well as solve the teacher`s problem in improving the students` achievement. Besides that, STAD learning model could improve the level of students` mastery learning. After implementing STAD, the students are expected to be more enthusiastic and active in social studies learning. Thus, teachers need a learning media to support the learning process. Based on the regulation of the Ministry of Education and Cultural of the Republic of Indonesia, Number 65 of 2013 defines the learning media as a learning process tool for delivering knowledge and information. Following this regulation, the learning media could be in the form of pictures, sound recording, television, a model, and out-door laboratory that could support social science learning.

Based on the above description, this research aims to: (1) measure the effectiveness of the implementation of learning model STAD using natural resources video to improve the students' learning motivation, (2) measure the effectiveness of the implementation of learning model STAD using natural resources video to improve the students`learning achievement.

\section{METHOD}

This research is action research. In this research, the teacher has a role in planning, implementing, and reflect the learning activity to improve the teachers' performance and students`achievement (Kusumah, 2010: 9). This class action research was improvement oriented that focused on improving the existing condition to become better. 
Another definition of classroom action research is research to improve education by improving many aspects of the learning process (Arikunto, 2010). The classroom action research is the representation of a collaborative participation activity held by a teacher in a school or the classroom. In this research approach, the teacher acts as a facilitator in order to collect the new perspectives regarding the learning activities. This perspective is aiming to improve learning activities in the school (Basrowi, 2008: 25).

\section{RESULT AND DISCUSSION}

\section{Learning Achievement}

Learning achievement is the result of the learning process that is achieved by someone through a particular activity. Gagne stated that learning achievement differentiated into five aspects: the intellectual skill, cognitive strategy, verbal information, skill, and attitude. Meanwhile, according to Bloom, the learning achievement is differentiated into three aspects: cognitive, affective, and psychomotor (Arikunto, 1990: 110)

In line with this argumentation, Winkel stated that the learning activity is the proof of success that is achieved by someone. Therefore, learning activities is the maximum efforts that are achieved by someone after implement the learning process. Meanwhile, according to Gunarso (1993: 77), learning activity is the maximal efforts that are achieved by someone after passed the learning activities.

The learning achievement in the educational field is the measurement of students`skill level after include in a learning activity. The measurement focuses on three aspects, encompassing cognitive, effective, and psychomotor. Thus, the students`skill level measured with the relevant test instrument. Thus, learning achievement is the result of the measurement of the assessment of learning effort, which is the numerical of verbal symbols that represent the students` level skill in a particular period. The learning achievement is the result of students`skill level measurement that covers the cognitive, affective, and psychomotor aspects of students.

The test of learning achievement measures learning achievement. According to Azwar (2005: 8-9), perceived on its purposes, the test of learning achievement has purposed to reveal the level or score of students` learning achievement. Test of learning achievement, in essence, is a process of collecting the data and then elucidate some factors that affected the student's learning achievement. This information is the base for decision making in the learning process. The test of learning achievement reveals the maximal performance of the students, particularly in mastering the materials that teach in the learning process. On formal education, the test of learning achievement is the daily test, formative evaluation, summative evaluation, and in the national examination test. From that description, the authors state that the definition of learning achievement is the level that can be achieved by students after the students follow the learning process, in which the student gets knowledge, experience, and skill. 
Based on the current observation, the authors found that the students' learning achievement in the subject of social science studies is low. The students` average score in the precycle was still under the minimum graduation criteria below 70 . The students also could not understand well the learning material, which they learned in during the learning process in the classroom. Also, based on the interview, the authors found that students feel bored with the existing model in the daily learning process.

In the student's perspectives, teachers commonly use talk learning model when they teach in the classroom. As a result, the students feel sleepy, bored, and saturated. These students' feeling affected the effectiveness of the learning process: the students could not well accept the learning material. Thus, the students feel difficult to accomplish the test, so the students' achievement level becomes low. Based on those problems, this research employed Student Teams Achievement Division (STAD) as the learning strategy. This model was used based on the purposes that the students should well accept the learning material.

The activity in pre cycle consists of four stages encompassing planning, implementation, observation, and reflection. The results of the pre-cycle show that from 31 students, there were 19 students achieve the minimum criteria of achievement, and 12 students still under the minimum criteria. From this data, the authors calculated that classical completeness was $61 \%$.

In the Cycle, I, the implementation of STAD learning model consists of six learning stages. From those learning stages, the authors found some lacks including insufficient of phases and times in the formation of learning group, excessive of the number of students in the groups, students unable to describe their work papers, students who had more knowledge tend to dominate the discussion, and the cooperative learning have not done well by the students.

The result of students' learning achievement in Cycle I showed that from 31 students, 21 students reach the minimum achievement criteria. Meanwhile, ten students were under the minimum achievement criteria. From this data, the classical completeness reaches $67 \%$ of the expected values of $85 \%$.

Based on the result of Cycle I, the authors then modified the STAD learning stages. The modified learning stages as follows: (1) the learning group formation with fewer number of the students (4 students), (2) giving learning motivation to the students, for example to read more thoroughly, (3) guide the student to learning cooperatively by habituating to discuss with other, (4) guiding the student to be more active in answering the question in the discussion stage.

The result of student's learning achievement in the classical approach of the Cycle I reaches the score $70.97 \%$ from the expected values at $85 \%$. Twenty-two students reached minimum graduation criteria, and nine students were still under the minimum graduation criteria. Based on these scores, the authors prepared the students to be ready for the next learning process by introducing some references and learning materials. Students noticed the teacher`s 
explanation regarding the learning material and the STAD`s stages. Teacher directed students to learn cooperatively in-group discussion. In more details, teachers directed the students to learn actively, particularly in asking or answering the question during the learning process.

From Cycle I, the authors found that the six learning stages in STAD must revise with some remark's points. First, several students could not describe clearly the worksheet in the presentation. Second, the inequality of student's activeness during the learning process. Third, the cooperative learning approach had not been implemented well in the discussion.

Furthermore, in Cycle II, the student's scores conducted from the observation of students exercise of multiple choice in the economic matter. In Cycle II, the score of student`s achievement showed that 25 students achieve minimum graduation criteria. Meanwhile, six students were under the criteria. Based on the data, the authors found the improvement of the students learning achievement score in the classical passing grade, from the Cycle I at 70,97 \% to 80,65 \% in Cycle II.

In Cycle III, the learning process is explaining the learning material of the utilisation of natural resources. The learning process corresponds to the lesson plan. The lesson plan contained the STAD learning stages and already done successfully. The result of the learning process was as follow: (1) students able to describe the worksheet in the front of the classroom, (2) a democratic nuance among students embarked on the discussion, (3) the cooperative learning implemented in the learning process. The result of students` score in Cycle III showed that 27 students achieved the minimum graduation criteria. Meanwhile, four students were under the criteria. The students score in Cycle III showed the improvement of a classical passing grade, from 80,65 \% in Cycle II to $87,09 \%$ in Cycle III.

Also, the result of learning achievement test showed the fruits of the learning process in improving the students` learning achievement. The actions, which were intervened in the Cycle I, Cycle II, and Cycle III, had shown that the implementation of STAD learning strategy could significantly improve the students` learning achievement in the social science learning process.

The result of research confirms the relevance, whether in theoretical or practical aspect, the implementation of STAD and the learning achievement. The improvement of students achievement, which obtained on the pre-cycle, Cycle I, Cycle II, and Cycle III saw in Table 2 and Chart 1.

Tabel.2. The comparison of the students`score

\begin{tabular}{cccccc}
\hline \multirow{2}{*}{ No } & \multirow{2}{*}{ Indicators } & \multicolumn{5}{c}{ Score } \\
\cline { 3 - 6 } & & Pre-cycle & Cycle I & Cycle II & Cycle III \\
\hline 1 & Lowest score & 45 & 45 & 55 & 60 \\
\hline 2 & Higher score & 80 & 85 & 85 & 95 \\
\hline
\end{tabular}




\begin{tabular}{cccccc}
\hline 3 & The completeness & $69.29 \%$ & $70.97 \%$ & $80.65 \%$ & $87.09 \%$ \\
\hline 4 & Average score & 61 & 70.16 & 72.09 & 76.13 \\
\hline
\end{tabular}

Chart 1. The comparison of the students`score

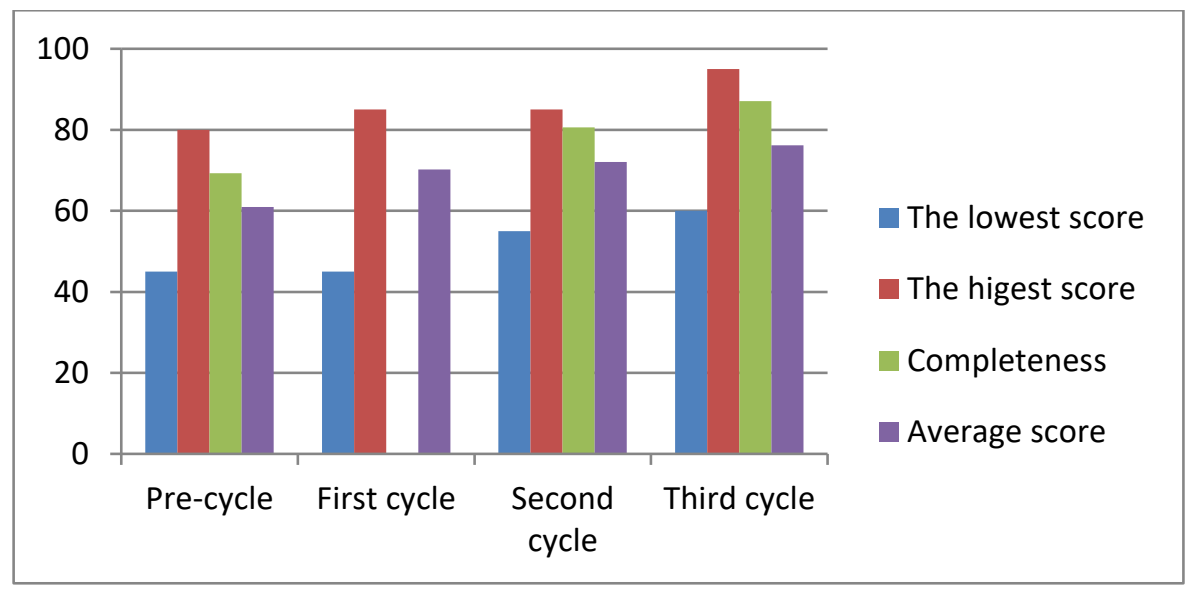

The Table 2 and Chart 1 depict that the actions, which taken from Cycle I, Cycle II, and Cycle III, successfully improved the students` completeness at $85 \%$ of the students who had passed the minimum graduate criteria. Thus, based on the result of research, the authors conclude that the implementation of STAD learning model significantly improves the student's achievement in learning social science.

\section{Learning Motivation}

Motivation etymologically refers to a human`s drive to take some actions, whether in consciously or unconsciously situation. In the subject of psychology, motivation defines as efforts that cause somebody or groups to take actions or pursue their objectives. According to Koeswara, motivation is perceiving as a mental effort that driving and guiding the human`s behaviour including the learning behaviour. It means that motivation consists of a willingness that activates as well as affects the learning attitude and behaviour of students (Dimyati, 2009: 80),

This definition is in line with Sardiman`s concept that defines motivation as a series of an efforts to provide a particular condition so that somebody is ready to take actions, and in the opposite, somebody could reject the feeling if he is unwilling to take some actions. Thus, motivation is all of the impetus of students, in which came internality or externality, by creating a series of efforts to provide a particular condition to drive the human to achieve their objectives (Sardiman, 2014)

The several aspects consider for measuring the learning motivation. First, the score of learning motivation in the Cycle I conduct for 30 item questions in motivation questionnaire, which consist of 18 actual item questions and 12 negative items questions. The result of the questionnaire shows the average score of students` learning motivation at 95, 52 from the 
maximal score of 120. Second, the questionnaire of learning motivation was too general, so it was inappropriate with the learning material. Third, the researchers modified several items of the questionnaire in order to improve student's comprehension of learning matter. The students have high learning motivation score if the questionnaire score is above the average score. Meanwhile, the student in the low learning motivation score if the learning motivation score is under the average score.

In the first cycle, 18 students (58,06 \%) have high learning motivation and 13 students $(41,94 \%)$ have low learning motivation. The percentage of learning motivation in the first cycle reached $74,19 \%$. It was under the expected percentage at $80 \%$. The authors tried to improve the result of the first cycle by modifying some aspect. First, the teacher should give a direction to students, particularly to fulfil the learning motivation questionnaire. Second, the questionnaire of learning motivation synchronises with the learning matter. Third, teacher should replace the items number 3, 5, 8, 10,11,12,13,14,16,17, 22, 26, 28, and 29.

In the second cycle, the score of students' learning motivation improved from 74,19\% to $77,42 \%$ in the second cycle. Meanwhile, the student's average score was 95,52 in the first cycle then improved to 97,64 in the second cycle. Based on the data, the authors found that 24 students (78 \%) had high learning motivation, and seven students (23\%) had low learning motivation.

In the third cycle, the score of students' learning motivation improved from $77,42 \%$ in the second cycle to 83,97 \% in the third cycle. The student's average score was 97,65 in the second cycle and improved to $98,77 \%$ in the third cycle. Based on the data of the third cycle, the authors found that 26 students $(83,87 \%)$ have high learning motivation, and five students $(16,13 \%)$ have low learning motivation. The result of class observation also confirms the improvement of learning motivation, which means that the actions in each cycle are successfully and effectively to scaffold the student's learning motivation. It can saw on the table below, which consist of a comparison of the result of the learning process in each cycle.

Table.3. The comparison of student`s learning motivation score in each cycle

\begin{tabular}{ccccc}
\hline \multirow{2}{*}{ No } & \multirow{2}{*}{ Indicators } & \multicolumn{3}{c}{ Students Score } \\
\cline { 3 - 5 } & & Cycle I & Cycle II & Cycle III \\
\hline 1 & The lowest scores & 83 & 86 & 87 \\
\hline 2 & The highest scores & 107 & 108 & 111 \\
\hline 3 & Completeness & 74.19 & 77.42 & 83.87 \\
\hline 4 & Average scores & 95.52 & 97.65 & 98.77 \\
\hline
\end{tabular}

Chart 2. The chart of the comparison of student`s learning motivation in each cycle 


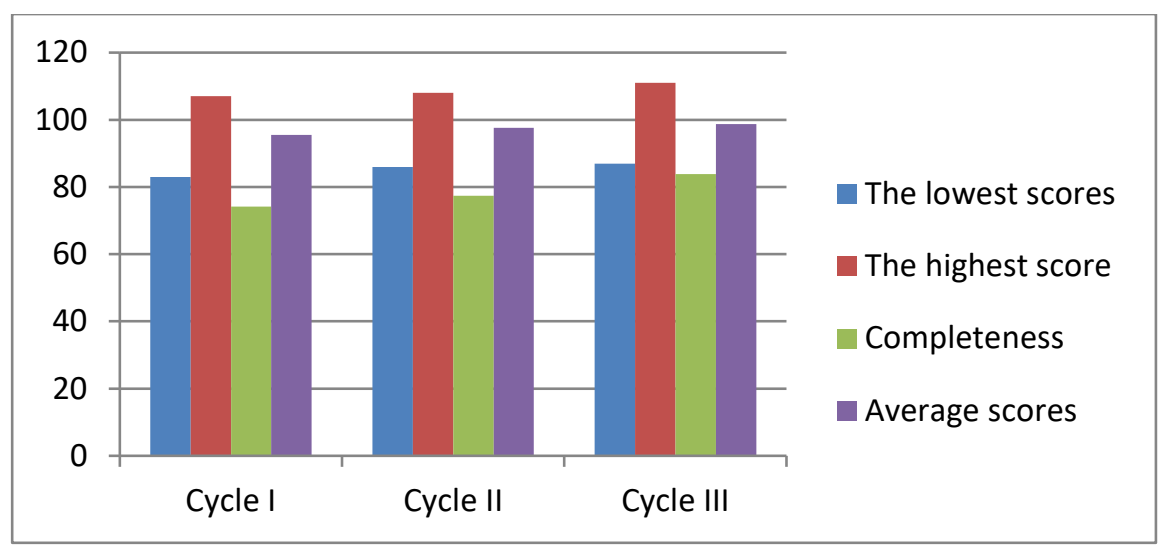

From the result above, the authors conclude that the implementation of STAD learning model, which imparted in each cycle, could improve the student`s learning motivation.

\section{CONCLUSION}

Based on the result and discussion of research, the authors conclude some points of research. First, the implementation of cooperative learning, particularly the STAD learning model with a video learning of potency and utilisation of natural resources, can significantly improve the student's learning motivation. It proved from the result of questionnaires in Cycle III that show the average score of student's learning motivation is $83,97 \%$.

The supporting of the level of student's learning motivation is the spiritual attitude and social attitude of the students. The score of student`s spirituality can be categorised in the high score at 84,48 \% in Cycle III. Meanwhile, the score of a student's social attitude on Cycle III reaches 83,76 . Second, the implementation of STAD learning model with a video learning of potency and utilisation of natural resources can improve the student's learning achievement. The result of the test achievement in Cycle III that shows the average score of the students reaches 76,13, and classical completeness is $87,09 \%$. It means that there are4students from 31 students who under minimal graduation criteria at 70 .

\section{REFERENCES}

Basrowi dan Suwandi, 2008. Prosedur Penelitian Tindakan Kelas. Bogor :Ghalia Indonesia.

Dimyati dan Mujiono.2009. Belajar dan Pembelajaran, Jakarta: Rineka Cipta

Sardiman A.M. 2014, Interaksi dan Motivasi Belajar Mengajar, Depok : PT Raja Grafindo

Suharsini Arikunto, 2010, Prosedur Penelitian.Jakarta: Rineka Cipta

Rusman ,2012, Model-Model Pembelajaran Mengembangkan Profesionalisme Guru, Jakarta: PT Raja Grafindo Pustaka

Wijaya Kusumah dan Dedi Dwitagama. (2010). Mengenal Penelitian Tindakan Kelas.Jakarta: Indeks 